\title{
SRA. FØNSS
}

\section{FRU FØNSS}

Autor: JACOBSEN, Jens Peter

Tradutores: ZWICK, Ludmila Menezes ${ }^{1}$ e ZWICK, Renato ${ }^{2}$

RESUMO: Tradução, do dinamarquês ao português, do conto "Sra. Fønss" (1882), de Jens Peter Jacobsen (1847-1885).

PALAVRAS-CHAVE: Jens Peter Jacobsen, Conto, Tradução dinamarquês-português

ABSTRACT: Translation, from Danish to Portuguese, of the short story "Mrs. Fønss" (1882), by Jens Peter Jacobsen (1847-1885).

KEYWORDS: Jens Peter Jacobsen, Short Story, Danish-Portuguese Translation

\section{APRESENTAÇÃ̃O}

\begin{abstract}
Se a marca de um grande artista é a capacidade de apresentar múltiplas verdades contraditórias ao mesmo tempo - a magnitude darwinista da vida, por um lado, digamos, e a terrível solidão, a tremenda futilidade da existência humana, por outro -, então Jacobsen certamente está entre os maiores (JENSEN, 2017, p. 190).
\end{abstract}

Se considerarmos o pouco tempo de vida de Jens Peter Jacobsen e, com isso, o pouco que ele escreveu, veremos que esse pouco é desproporcional ao muito que ele influenciou sua geração. Nascido em 1847 na pequena Thisted, uma cidade portuária nos confins da península

\footnotetext{
${ }^{1}$ Doutora em Letras (Literatura e Cultura Russa) pela Universidade de São Paulo. E-mail: apuslynx @ gmail.com. 2 Mestre em Letras (Língua e Literatura Alemã) pela Universidade de São Paulo. E-mail: renatozwick@ hotmail.com.

${ }^{3}$ Baseada no recente trabalho de Morten Høi Jensen, A Difficult Death: The Life and Work of Jens Peter Jacobsen, publicado em 2017 pela editora da universidade de Yale.
} 


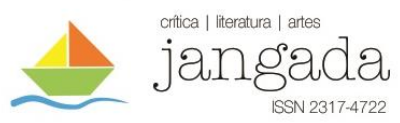

dinamarquesa, ele finalizou dois romances, Niels Lyhne $e^{4}$ e Marie Grubbe $e^{5}$, uma coletânea de poemas e seis narrativas curtas. Em 1885, após completar trinta e oito anos, o autor morreu vitimado pela tuberculose que o acompanhava desde sua última viagem à Europa. "Sua vida foi cruelmente circunscrita; nunca se casou, não teve filhos e passou a maior parte de sua vida adulta na casa dos pais, definhando silenciosamente e trabalhando pacientemente em sua escrita" (JENSEN, 2017, p. xxix).

Para Jensen (idem, p. xxx), a história de Jacobsen acompanha a história de inúmeras transformações na cultura e na política escandinavas; sem vínculo político, o autor abalou as estruturas religiosas com suas traduções de A origem das espécies e A descendência do homem, de Charles Darwin. Na vanguarda de um movimento que lutava para definir os termos do que deveria ser totalmente moderno ${ }^{6}$, era amigo e aliado de Georg Brandes em sua cruzada contra o idealismo romântico e o conservadorismo pastoral da vida cultural dinamarquesa. A obra Niels Lyhne, em particular, figura então como um dos grandes romances da experiência da modernidade, um retrato da desorientação e da vertigem da vida moderna, à altura dos escritos de Dostoiévski, Thomas Hardy e Nietzsche.

A ficção de Jacobsen, na percepção de Jensen (idem, p. xxxi), parte de muitas horas de solidão e sofrimento, geradoras de obras sem cinismo e sem esperança, sem o falso conforto das religiões frente à morte. Como cientista, ele entendia que esta é tão somente a finalizadora de nossa existência material, mas também compreendia que a religião satisfazia uma necessidade humana cuja base seria o desejo ilusório de prolongar a vida além da morte. Como artista, ele próprio confessou ser preguiçoso, dado a sonhar acordado e ser capaz de passar muitas horas por dia sem fazer absolutamente nada. Em uma carta a Axel Helsted, comparou a atividade de escritor à de Sísifo; as frases rolariam montanha abaixo repetidas vezes (idem, pp. 125-126).

\footnotetext{
4 "Niels Lyhne é um relato surpreendentemente cândido e vigoroso das ambiguidades do ateísmo. Para Jacobsen, o ateísmo não era simplesmente uma ideia, uma postura radical; foi um compromisso moral difícil. Apesar dos protestos em contrário, ele levou o ateísmo muito mais a sério do que qualquer de seus contemporâneos" (JENSEN, 2017, p. 141).

${ }^{5}$ Em março de 1873, Jacobsen escreveu a Edvard Brandes que acordava todos os dias às onze e seguia rumo à Biblioteca Real, onde lia velhos documentos, cartas e descrições de assassinatos, adultério e prostituição, preços de mercado, jardinagem, processos de divórcio, batismos, registros de propriedade, genealogias, sermões fúnebres etc. para compor um magnífico romance intitulado Marie Grubbe (idem, p. 80).

${ }^{6}$ Jacobsen estudou em Copenhague, que "foi o primeiro campo de batalha real do modernismo europeu". Brandes realizara uma série de palestras sobre as principais correntes literárias da época, após as quais a noção de "moderno" se tornou um slogan programático em torno do qual os escritores se reuniam. E, embora a visão de Brandes da literatura moderna fosse explicitamente sociopolítica e realista, sua influência se mostrou mais expansiva e cosmopolita (idem, p. 103).
} 
O poeta alemão Rainer Maria Rilke teria sido apresentado a Jacobsen numa época em que esse autor estava no auge de sua fama póstuma, pois havia na cultura literária alemã uma inspiração baseada nos novos movimentos nas letras escandinavas e, em particular, no trabalho de Jacobsen, Henrik Ibsen, August Strindberg, Herman Bang e Knut Hamsun. Assim, a partir de 1890, Jacobsen tornou-se uma figura literária de culto nos países de língua alemã da Europa, tendo sua obra traduzida em círculos artísticos de Viena a Berlim e seus poemas musicados por artistas como Arnold Schoenberg e Alexander von Zemlinsky. As edições de Niels Lyhne venderam milhares de cópias em seis anos. Stefan Zweig chamou Niels Lyhne de o Werther de sua geração, enquanto a crítica e tradutora Marie Herzfeld o teria classificado como uma espécie de livro de orações para os jovens pintores e poetas. Freud teria ficado perplexo com ele, Robert Musil quase copiou uma cena dessa obra e Gottfried Benn o carregava onde quer que fosse (JENSEN, 2017, p. xxviii). ${ }^{7}$

A essa altura, esclarece Jensen (idem, p. xxviii-xxix), a influência de Jacobsen estendera-se para além da Europa continental. Na Grã-Bretanha, foi avidamente lido por George Gissing, T.E. Lawrence e Henry Handel Richardson e considerado por James Joyce como um dos sucessores de Flaubert. O filho de Boris Pasternak afirmou que Niels Lyhne tinha um lugar permanente na mesa do pai durante os anos que passara escrevendo Doutor Jivago. O autor teria influenciado inclusive as escritoras Nella Larsen e Zora Neale Hurston, do movimento Renascimento do Harlem, por meio da tradução do romance Marie Grubbe.

Jacobsen (idem, p. xxi-xxiv) fora o único companheiro real de Rilke em Viareggio. O poeta carregava seus livros e tinha o mesmo desejo de conhecê-lo que tivera em relação a Rodin, mas terminou por descobrir que o escritor dinamarquês estava morto há muito tempo. O jovem poeta percebeu que Jacobsen podia discorrer com precisão quase científica sobre a beleza do mundo natural, por ser um autor hábil em dissecar de modo lírico as flores, as árvores, sem deixar de sondar as profundezas mais solitárias da humanidade, suas mais profundas decepções e suas mais sombrias dúvidas. Nas cartas de Rilke, o nome de Jacobsen aparece frequentemente ao lado do de Rodin. Isso se deve ao fato de que, como o escultor, o poeta dinamarquês era um artista cuja observação cuidadosa do mundo natural lhe permitia transformar essa experiência em uma arte perfeitamente formulada. Após cansar-se da capital francesa, que parecia a Rilke

\footnotetext{
${ }^{7}$ A Escandinávia era então "a terra prometida da literatura", enquanto alguns dos editores mais influentes da época, como Samuel Fischer e Albert Langen, ganharam proeminência em parte por causa de seus catálogos fortemente nórdicos. Até mesmo Thomas Mann, que afirmou ter "devorado" a literatura escandinava quando jovem, declarou em entrevista ser muito inclinado ao Norte, e ter de lá, como maior influência, J.P. Jacobsen (JENSEN, 2017, p. xxviii).
} 
não um lugar festivo e vivaz, mas um lugar aonde as pessoas iam para perecer, por transbordar tristeza, ele rumou para a Riviera italiana, de onde, frustrado, viajou mais para o sul, para Viareggio, onde finalmente encontrou sua solidão criativa e de onde escreveu cartas ao poeta Franz Xaver Cappus, nas quais relata que, de todos os seus livros, apenas alguns lhe eram indispensáveis, e que dentre eles, apenas dois estavam com ele onde quer que fosse, a Bíblia e as obras de Jens Peter Jacobsen:

Obtenha o pequeno volume Seis histórias de J.P. Jacobsen e seu romance Niels Lyhne, e comece com a primeira história do primeiro, que se chama "Mogens". Um mundo virá sobre você, a felicidade, a abundância, a imensidão incompreensível de um mundo. Viva um pouco nesses livros, aprenda com eles o que lhe parecer digno de aprendizado, mas, acima de tudo, ame-os. Esse amor lhe será retribuído milhares e milhares de vezes (...) (RILKE apud JENSEN, idem, p. xxii-xxiii).

Em 1947, no Times Literary Suplement, num artigo acerca do centenário do nascimento de Jacobsen (JENSEN, idem, p. xxx), o autor anônimo afirmou que as virtudes do escritor dinamarquês haviam sido ofuscadas por Rilke; Jacobsen teria sido em boa medida engolfado pelos vários tributos e pela imitação que Rilke prodigalizou em sua memória. Contudo, argumenta o autor do artigo, se conseguirmos apreender Jacobsen sozinho por um instante, sem essa sombra, deparamo-nos com um talento extraordinário e comovente que figura entre os prodigiosos inválidos do século XIX.

Jacobsen não é autor para viver sob a sombra de outro, nem que esse outro seja Rilke; no âmbito do empenho de apreendê-lo sozinho, apresenta-se aqui a tradução de um de seus textos, a última das seis histórias mencionadas por Rilke, "Sra. Fønss". 


\section{Sra. Fønss}

Nos belos jardins atrás do antigo palácio dos papas em Avignon há um banco de observação de onde se avista o Ródano, a margem florida do Durance, colinas e campos e uma parte da cidade.

Numa tarde de outubro, estavam sentadas nesse banco duas senhoras dinamarquesas, uma viúva, a sra. Fønss, e sua filha, Ellinor.

Embora estivessem aqui há alguns dias, e embora já conhecessem muito bem a vista que se estendia à frente delas, não obstante ainda estavam sentadas e se admiravam de que tal fosse o aspecto da Provença.

Que essa realmente fosse a Provença! Um rio lamacento com flocos de areia lodosa e margens infinitas de cascalho cinza-pedra; e então, campos castanho-pálidos sem uma folha de relva, escarpas castanho-pálidas, colinas castanho-pálidas e caminhos de poeira clara, e, aqui e ali, junto às casas brancas, grupos de árvores negras, arbustos e árvores completamente negros. Sobre tudo isso, um céu esbranquiçado e tremeluzente que tornava tudo ainda mais pálido, ainda mais seco e cansativamente claro; nem um vislumbre de tonalidades viçosas e fartas, apenas cores famintas e torturadas pelo sol, e nem um som no ar, nem uma foice ceifando o capim, nem um veículo chacoalhando pelas estradas; e a cidade, ali, como que construída de silêncio de ambos os lados, com todas as ruas na calada do meio-dia, todas as casas surdasmudas com cada persiana, cada veneziana fechada, fechadas cada uma delas; casas que não podiam ouvir nem ver.

A sra. Fønss tinha apenas um sorriso resignado para essa uniformidade sem vida, mas a mesma deixava Ellinor visivelmente nervosa, não nervosa de uma maneira vivamente irritada, mas lamuriante e abatida, tal como podemos ficar devido ao tempo chuvoso que se estende por dias a fio, quando todos os nossos pensamentos tristes também chovem sobre nós, ou devido ao tique-taque idiotamente consolador de um relógio de parede, quando estamos sentados e nos detestamos incuravelmente, ou devido às flores em nosso papel de parede, quando a mesma cadeia de sonhos gastos se desfia em nosso cérebro contra a nossa vontade e se une e se faz em pedaços e se une outra vez numa infinitude nauseante. Ela a tocava de modo literalmente físico, essa paisagem, e quase a levava ao desfalecimento, tal era a maneira como hoje se conjurara com recordações de uma esperança que se partira e de sonhos deliciosamente doces que agora eram apenas languidamente nauseantes, sonhos que a deixavam enrubescida de vergonha ao 
recordá-los e que no entanto nunca podia esquecer. E o que mesmo isso tinha a ver com a região aqui? Afinal, o golpe a atingira longe daqui, nos arredores de sua casa, junto ao estreito cambiante, sob as faias verde-claras, e, no entanto, cada ondulação de encosta castanho-pálida tinha-o em seus lábios e cada casa de persianas verdes estava aí parada e se calava a respeito.

Ela se defrontara com a velha aflição dos corações jovens, ela amara um homem e acreditara no amor outra vez, e de súbito ele tinha escolhido uma outra; por quê, para quê? O que ela lhe fizera? Como ela se modificara, não era ela mais a mesma? E todas as eternas perguntas outra vez. Não dissera uma palavra à mãe, mas a mãe compreendera cada pedacinho e fora muito cuidadosa com ela; ela teria podido gritar por causa desse cuidado, que sabia e de forma alguma deveria saber, e a mãe também tinha compreendido isso, e assim elas tinham viajado.

Toda a viagem tinha apenas o propósito de que ela esquecesse.

A sra. Fønss não precisava constranger a filha ao examinar seu rosto para saber onde ela se encontrava; ela apenas lançou um olhar à pequena mão nervosa que estava ao seu lado, e que se retesava de maneira tão impotentemente desesperada nas ripas do banco a fim de mudar sua posição a cada momento, como uma pessoa febril que se mexe em sua cama quente: ela apenas fez isso, olhou para a mão dela, e então também soube quão cansados da vida os olhos jovens fitavam o nada, de que modo atormentado o rosto delicado estremecia em cada traço, como estava pálido em seu sofrer e de que maneira doentia as veias se destacavam azuladas sob a pele fina das têmporas.

Ela se sentia muito mal por sua garotinha e muito teria gostado de tê-la tido apoiada contra seu peito para exalar sobre ela todas as palavras de consolo que pudesse imaginar; contudo, ela acreditava que há mágoas que deviam morrer em segredo e não podiam obter permissão de bradar em palavras, nem sequer entre mãe e filha, de modo que um dia, sob novas circunstâncias, quando tudo quer se alçar rumo ao êxtase e à felicidade, essas palavras não sejam como um obstáculo, algo que oprime e priva da liberdade, pois aquele que as disse as ouvirá na mente do outro, sussurrando, imaginará tê-las visto, revolvidas e giradas nos pensamentos do outro.

E também, ela temia prejudicar a filha ao tornar-lhe fácil a confidência; ela não queria que Ellinor enrubescesse diante dela; ela não queria, por mais que isso pudesse trazer alívio, ajudá-la a superar a humilhação que há no fato de expor os recantos mais secretos de sua própria alma ao olhar de um outro: pelo contrário, por mais difícil que ainda fosse para ambas, tanto 
mais ela estava contente por reencontrar em sua jovem filha, numa certa rigidez sã, a nobreza de alma que havia nela própria.

Uma vez - uma vez há muitos, muitos anos atrás, quando ela mesma fora uma moça de seus dezoito anos, ela tinha amado de toda a sua alma, com cada sentido de seu corpo, cada esperança de vida, cada pensamento; e isso não pôde ser, não pôde perdurar; ele tivera apenas sua fidelidade a oferecer, para pôr à prova num noivado interminável, e havia circunstâncias na casa dela que não podiam esperar. Assim, ela aceitou aquele que lhe deram, aquele que era senhor dessas circunstâncias. Casaram-se, então vieram os filhos, Tage, o filho, que estava junto aqui em Avignon, e a filha que estava sentada ao lado dela, e isso se tornou muito melhor do que ela pudera esperar, tanto mais iluminado como mais leve. Isso durou oito anos, então morreu o marido e ela o chorou com um coração sincero, pois aprendera a gostar dessa natureza delicada, de sangue fino, que com um amor tenso, egoísta, amava quase doentiamente o que lhe pertencia por estirpe e laço familiar, e que em todo o grande mundo lá fora com nada se importava senão com o que este pensava, apenas com sua opinião, nada mais. Após a morte do marido, ela então vivera mais para seus filhos, mas não se trancara com eles, ela tomara parte da vida social, como era natural para uma viúva tão jovem e abastada, e agora seu filho tinha vinte e um anos de idade e a ela mesma não faltavam muitos dias até os quarenta. Mas ainda era bonita, não havia qualquer sombra cinzenta em seu cabelo pesado e louro escuro, nenhuma ruga em volta dos olhos grandes e francos, e a figura era esbelta em sua abundância com formas contidas. Os traços enérgicos, de linhas finas, eram realçados pela tez mais escura, de cor mais profunda, que os anos the haviam dado, mas havia uma doçura no sorriso em torno de seus lábios profundamente sinuosos, uma juventude quase promissora no brilho suavemente embaçado de seus olhos castanhos, que outra vez tornavam tudo brando e alegre. E, no entanto, havia, por sua vez, a redondeza séria e grande das bochechas, o queixo resoluto da mulher madura.

- Agora Tage vem com certeza - disse a sra. Fønss à filha ao ouvir risadas e algumas exclamações em dinamarquês do outro lado da espessa cerca viva de álamos-brancos.

Ellinor se conteve.

E era Tage, Tage e os Kastager, o atacadista Kastager de Copenhague com a irmã e a filha; a sra. Kastager ficara no hotel, de cama.

A sra. Fønss e Ellinor deram lugar às duas damas, os senhores tentaram por um momento conversar em pé, mas logo se deixaram atrair pelo muro baixo de granito que circundava o 
miradouro, e assim estavam todos ali sentados e conversavam apenas o mais necessário, pois os recém-chegados estavam cansados de um pequeno passeio de trem pela Provença chamejante de rosas.

- Ei! - gritou Tage e bateu com a palma da mão em suas calças claras -, olhem lá!

Eles olharam.

Ao longe, na paisagem castanha, assomava uma nuvem de poeira, acima dela um manto de poeira e em meio a ambas se avistava um cavalo.

- É o inglês de quem falei, que chegou no outro dia - disse Tage dirigindo-se à mãe. O senhor já viu alguém cavalgar assim? - ele se voltou a Kastager -, ele me lembra um gaúcho.

- Mazeppa? - disse Kastager em tom interrogativo.

O cavaleiro desapareceu.

Então levantaram-se e tomaram o caminho do hotel.

Haviam encontrado esses Kastager em Belfort, e como fariam a mesma viagem, descendo pelo sul da França e ao longo da Riviera, eles os acompanhavam por ora. Aqui em Avignon ambas as famílias fizeram uma parada, a do atacadista porque sua mulher fora acometida por uma variz, os Fønss porque Ellinor claramente precisava de sossego.

Tage estava entusiasmado com essa convivência, pois dia após dia se enamorava mais e mais incuravelmente da amável Ida Kastager, mas a sra. Fønss não estava tão contente, pois por certo Tage era muito seguro e desenvolvido para a sua idade, mas não havia pressa alguma com qualquer noivado, e ainda por cima esse Kastager. Ida era uma mocinha esplêndida, a sra. Kastager era uma dama muito culta de excelente família e o próprio atacadista era tão habilidoso e rico quanto honesto, mas pairava sobre ele um quê de ridículo, e vinha um sorriso aos lábios das pessoas ou um brilho aos seus olhos quando se mencionava o atacadista Kastager. É que ele era tão impetuoso e tão extraordinariamente entusiasmado, era-o de modo tão franco, tão ruidoso e tão expansivo, e essa era a razão, pois se requeria justamente tanta discrição para lidar com o entusiasmo. Porém, a sra. Fønss não gostava de pensar que o sogro de Tage fosse mencionado com um brilho nos olhos, um sorriso na boca, e por isso ela se mantinha um pouco fria em relação à família, para grande pesar do apaixonado Tage.

Na manhã do dia seguinte, Tage e sua mãe foram ver o pequeno museu da cidade. Encontraram os portões abertos, mas fechadas as portas da coleção; e tocar a campainha mostrou-se infrutífero. Entretanto, os portões davam acesso ao pátio não muito grande, que era 
cercado por uma arcada de caiadura recente, cujas colunas baixas e corpulentas escoravam-se mutuamente com barras de ferro pretas.

Eles deram uma volta e olharam para o que estava colocado ao longo das paredes: lápides romanas, fragmentos de sarcófagos, uma figura drapejante sem cabeça, duas vértebras de baleia e uma série de detalhes arquitetônicos.

Sobre todas as curiosidades havia o vestígio fresco da brocha de caiar do pedreiro.

Então estavam outra vez no seu ponto de partida.

Tage correu escada acima para ver se afinal não poderia haver pessoas em algum lugar da casa, e a sra. Fønss começou a passear para a frente e para trás na arcada.

Quando estava a caminho dos portões, apareceu no final do trajeto, diretamente à frente dela, um senhor alto e barbudo com o rosto queimado de sol. Tinha nas mãos um guia de viagens, prestou atenção a algo atrás de si e então olhou para a frente, para ela.

Pensou de imediato no inglês de ontem.

- Perdão, senhora - começou ele interrogativamente, e saudou.

- Sou estrangeira - respondeu a sra. Fønss -, parece não haver ninguém em casa, mas meu filho correu para o andar de cima a fim de ver se...

Trocaram essas palavras em francês.

No mesmo instante, chegou Tage.

- Fiz toda a volta - disse ele -, entrei até num aposento, mas não encontrei sequer um gato.

- Ouço - disse o inglês, desta vez em dinamarquês - que tenho o prazer de estar com compatriotas.

Ele cumprimentou outra vez e deu alguns passos para trás, como que para indicar que apenas dissera isso para que soubessem que entendera o que tinham dito; mas, de repente, chegou ainda mais perto do que antes, com uma expressão tensa e comovida no rosto, e disse:

- Será que a senhora e eu não somos velhos conhecidos?

- É Emil Thorbrøgger? - exclamou a sra. Fønss, e estendeu a mão.

Ele a tomou.

- Sim, sou eu - disse ele contente -, e aí está a senhora!

Ele quase tinha lágrimas nos olhos ao olhar para ela.

A sra. Fønss apresentou Tage como filho dela. 
Jamais em sua vida Tage ouvira mencionar esse Thorbrøgger, mas ele não pensava nisso, apenas no fato de o gaúcho ter se revelado um dinamarquês, e como surgiu uma pausa, e alguém tinha de dizer alguma coisa, ele não pôde deixar de exclamar:

- E eu que disse ontem que o senhor me lembrava um gaúcho!

Sim, respondeu Thorbrøgger, isso também estava bem perto da verdade, uma vez que durante 21 anos vivera no meio das planícies de La Plata e, por certo, em todos esses anos, estivera mais a cavalo do que a pé.

E agora ele tinha retornado à Europa!

Sim, agora ele vendera suas terras e suas ovelhas e viera dar uma olhada nesse velho mundo ao qual pertencia; mas, com vergonha de falar a respeito, tinha de dizer que com frequência achara muito enfadonho viajar desse modo para seu prazer.

Tinha ele porventura saudade das pradarias?

Não, ele jamais tivera qualquer nostalgia de lugares e países, acreditava apenas sentir falta do trabalho diário.

Assim conversaram por um momento. Finalmente chegou o zelador, acalorado e ofegante, com cabeças de alface debaixo do braço e um maço de tomates vermelho-fogo na mão, e eles foram admitidos na pequena e abafada pinacoteca, onde apenas obtiveram a mais vaguíssima impressão das nuvens de tempestade amareladas e das águas enegrecidas do velho Vernet, enquanto, em compensação, familiarizaram-se muito bem com a vida e o destino mútuos nos muitos anos transcorridos desde que se separaram.

Pois fora ele quem ela amara daquela vez quando se ligou a outro; e nos dias que agora se seguiram, quando estavam bastante juntos, e quando os demais, sentindo que amigos tão velhos deviam ter muito a dizer um ao outro, deixavam-nos com tanta frequência sozinhos, nesses dias, ambos logo perceberam que, por mais que tivessem mudado no correr dos anos, seus corações nada tinham esquecido.

Talvez tenha sido ele quem primeiro percebeu isso, pois toda a insegurança da juventude, seu sentimentalismo e seus anseios elegíacos tomaram conta dele de uma só vez, e ele sofreu com isso; causava aversão ao homem maduro ser privado de um só golpe da paz na vida, da autoconfiança adquirida com o tempo, e ele desejou seu amor cunhado de outro modo, quis que ele fosse mais digno, mais sereno.

Ela não se sentia mais jovem, parecia-lhe, mas era-lhe como se em sua alma uma torrente de lágrimas contida, represada, irrompesse novamente e voltasse outra vez a fluir; e 
chorar era algo muito venturoso e aliviador, e ela tinha um sentimento de riqueza frente a essas lágrimas, como se ela tivesse mais valor e tudo lhe tivesse mais valor outra vez; um sentimento de juventude, enfim.

Numa noite de um desses dias, a sra. Fønss estava sentada, sozinha, no hotel; Ellinor deitara-se cedo e Tage fora com os Kastager ao teatro. Estivera ali sentada no fastidioso quarto de hotel e sonhara na semiescuridão que algumas velas podiam criar até que os sonhos estacaram no seu incessante ir e vir, e ficara cansada, mas era o cansaço suave e sorridente que se espalha sobre alguém quando pensamentos felizes estão adormecendo em sua mente.

Não podia ficar a noite inteira ali sentada a olhar para o vazio à sua frente sem ter sequer um livro, e ainda levaria mais de uma hora até a peça de teatro terminar; assim, começou a andar para cima e para baixo pelo quarto, parou diante do espelho e arrumou seu cabelo.

Poderia descer ao gabinete de leitura e passar os olhos nas revistas ilustradas. Lá estava sempre vazio a essa hora da noite.

Lançou um grande véu negro de renda sobre a cabeça e desceu.

Sim, estava vazio lá.

A sala pequena e densamente mobiliada estava iluminada de maneira ofuscante por uma meia dúzia de grandes lâmpadas a gás; estava quente lá dentro, e o ar, de uma secura quase abrasadora.

Ela puxou o véu para baixo, envolvendo os ombros.

Os jornais brancos ali sobre a mesa, as pastas com suas grandes letras douradas, as cadeiras de veludo vazias, os quadrados regulares do carpete e as pregas uniformes das cortinas de repes, tudo isso parecia tão mudo nessa luz forte.

Ela ainda sonhava e, sonhando, ficou parada e escutou o canto das lâmpadas a gás ressoando longamente.

Quase se podia ficar tonto do calor.

Lentamente, a fim de se apoiar, estendeu a mão para um grande e pesado vaso de bronze que estava colocado num consolo preso à parede e agarrou sua borda florinodosa.

Era cômodo ficar assim parada, e o bronze era tão agradavelmente frio à sua mão. Mas, ao estar ali de pé, sobreveio-lhe uma outra coisa. Começou a senti-la como um contentamento por seus membros, por seu corpo, pela posição escultoricamente bela em que mergulhara, e a consciência do quão bem ela lhe assentava, da beleza que pairava sobre ela nesse instante, e 
mesmo a sensação física de harmonia, isso se reunia num sentimento de triunfo, fluía através dela como um estranho júbilo festivo.

Ela se sentia tão forte nesse momento, a vida estava diante dela como um grande e radiante dia, e não mais como um dia que declina rumo às horas quietas e cheias de melancolia do crepúsculo, mas como um grande e desperto período de tempo, com pulsos quentes batendo a cada segundo, com a volúpia da luz, com ação e com pressa e uma infinitude por fora e por dentro. E ela se entusiasmava com a plenitude da vida e ansiava por ela com a vertigem e o ardor da febre que precede uma viagem.

Ficou parada dessa maneira por longo tempo, fascinada com seus pensamentos, esquecendo tudo à sua volta. Então, de repente, foi como se ouvisse o silêncio lá dentro, o canto das chamas a gás ressoando longamente, e deixou a mão cair do vaso, sentou-se à mesa e começou a folhear uma pasta.

Ouviu passos que passaram diante da porta, ouviu-os dar meia-volta e então viu Thorbrøgger entrar.

Trocaram algumas palavras, mas como ela parecia absorta em suas ilustrações, ele também começou a olhar os jornais que ali estavam. Entretanto, estes não o interessaram muito, pois quando ela ergueu os olhos um pouco depois, encontrou o olhar dele, que a fitava esquadrinhador.

Ele parecia estar prestes a falar, e em torno de sua boca havia uma expressão nervosa e resoluta que lhe dizia tão decididamente quais palavras seriam que ela enrubesceu e, instintivamente, como que para detê-las, estendeu-lhe sua revista ilustrada sobre a mesa e apontou para um desenho de alguns cavaleiros do pampa que laçavam touros selvagens.

Ele também estava prestes a se deixar levar a um gracejo sobre as ideias ingênuas do ilustrador acerca da arte de laçar; era tão tentadoramente fácil falar a respeito, em contraste com aquilo que tinha em mente, mas pegou a revista de modo resoluto e a empurrou para o lado, curvou-se um pouco à frente sobre a mesa e disse:

- Pensei tanto na senhora desde que nos encontramos, sempre pensei tanto na senhora, tanto daquela vez na Dinamarca como lá onde estive. E sempre a amei, e quando agora me parece às vezes que nunca a amei mais do que agora, ao nos encontrarmos outra vez, isso não é verdade, por maior que também seja meu amor, pois sempre a amei, amei-a sempre. E se agora me fosse permitido tê-la, a senhora não poderia compreender o que seria para mim se a senhora, que foi tirada de mim por tantos anos, quisesse retornar! 
Ele se manteve em silêncio por um momento, então se ergueu e se aproximou dela.

- Oh, diga uma palavra, estou aqui parado e falo como que às cegas, tenho de falar com a senhora como a um intérprete, a um estrangeiro, que deve repetir o que digo ao coração a que falo, não sei... estar aqui parado e pesar minhas palavras... não sei o quão longe ou o quão perto, não me atrevo a dar voz à adoração que toma conta de mim - ou me atrevo?

Ele se deixou cair numa cadeira ao lado dela.

- Se me atrevesse, se não precisasse temer... é verdade! Oh, Deus te abençoe, Paula!

- Não há nada que deva nos manter separados por mais tempo - disse ela com sua mão na dele -, o que quer que aconteça, tenho o direito de ser feliz ao menos uma vez, de viver plenamente ao menos uma vez segundo minha natureza, de viver meus anseios e meus sonhos. Jamais me resignei; ainda que a felicidade não tenha chegado para mim, jamais acreditei que a vida fosse apenas mesquinhez e dever, eu sabia que havia pessoas felizes.

Em silêncio, ele beijou sua mão.

- Sei - disse ela tristemente - que aqueles que me julgarão da forma mais branda me concederão a felicidade de saber-me amada por ti, mas eles também dirão que isso deveria bastar-me.

- Mas isso jamais me bastaria, e jamais terias o direito de livrar-te de mim dessa maneira.

- Não - disse ela -, não.

Pouco depois, ela subiu até onde estava Ellinor.

Ellinor dormia.

A sra. Fønss sentou-se junto à sua cama e olhou para a filha pálida, cujos traços apenas podiam ser divisados indistintamente ao brilho amarelo e pobre da lamparina.

Tinham de esperar por causa de Ellinor. Dali a alguns dias, separar-se-iam de Thorbrøgger e iriam a Nice e lá ficariam sozinhos; ela viveria todo aquele inverno para recuperar a saúde de Ellinor. Mas, no dia seguinte, contaria aos filhos o que acontecera e o que estava por vir. Como quer que acolhessem isso, era-lhe impossível conviver com eles entra dia, sai dia quase apartada deles por tal segredo. E, afinal, também precisariam de tempo para se habituar à ideia; pois seria uma separação entre eles, se maior ou menor, isso dependeria dos próprios filhos. Quanto à ordenação de suas vidas na relação com ela e com ele, caber-lhes-ia determinar tudo. Ela nada exigiria. A este respeito, estava por conta deles conceder.

Ela ouviu os passos de Tage no interior do salão e foi ter com ele. 
Ele estava a um só tempo tão radiante e tão nervoso que a sra. Fønss logo pensou que acontecera algo, e ela também suspeitava o quê.

Mas ele, que queria encontrar uma espécie de introdução para o que tinha no coração, estava sentado e falava distraidamente sobre o teatro, e só quando sua mãe foi até ele e pôs a mão em sua testa, obrigando-o a erguer o olhar para ela, é que ele conseguiu contar que pedira a mão de Ida Kastager e que recebera um sim.

Falaram então longamente sobre isso, mas a sra. Fønss sentia o tempo todo que sobre aquilo que dizia pairava uma frieza que não conseguia superar, pois temia harmonizar-se em demasia com Tage por causa da comoção em que ela própria se encontrava, e ainda havia o fato de não poder suportar que seus pensamentos desconfiados se lançassem no rastro mesmo que da mais fraca sombra de ligação entre o fato de ser amigável esta noite e aquilo que contaria pela manhã.

Entretanto, Tage não percebeu qualquer frieza.

A sra. Fønss não conseguiu dormir muito nessa noite, ela tinha pensamentos demais a mantê-la acordada. Pensou no quanto era estranho que ele e ela se encontrassem e que, ao se encontrarem, ainda gostassem um do outro como nos velhos tempos.

No entanto, estes eram velhos tempos, sobretudo para ela, afinal não era mais jovem, não poderia mais sê-lo, de qualquer forma. E isso se tornaria evidente; ele teria de ser indulgente com ela, acostumar-se ao fato de que fazia muito que ela tivera dezoito anos. Mas ela se sentia jovem, era-o sob muitos aspectos, e, no entanto, tinha consciência de sua idade; via isso com muita nitidez: em mil movimentos, nas expressões faciais e nos gestos, no modo como atenderia a um aceno, no modo como sorriria ao dar uma resposta, dez vezes por dia se tornaria velha nisso, pois lhe faltaria coragem de ser no exterior tão jovem como em sua mente.

E os pensamentos iam e vinham, mas através de tudo isso irrompia sem cessar a mesma pergunta acerca de seus filhos, sobre o que diriam.

A manhã já ia avançada no dia seguinte quando ela pediu a resposta.

Estavam sentados no salão.

Ela disse que tinha algo importante a lhes comunicar, algo que causaria uma grande mudança para todos, algo que lhes sobreviria de modo muito inesperado. Pediu-lhes para ouvir o mais tranquilamente que pudessem e que não se deixassem levar a coisas irrefletidas pela primeira impressão; pois deveriam saber que aquilo que lhes contaria estava firmemente decidido e que nada que pudessem dizer a faria mudar de ideia. 
- Quero me casar outra vez - disse ela, e contou-lhes como amara Thorbrøgger antes de conhecer o pai deles, como fora separada dele e como agora tinham se encontrado.

Ellinor chorava, mas Tage se levantara de seu lugar, totalmente perplexo, fora até a mãe, ajoelhara-se diante dela e segurou sua mão, que ele, soluçando, meio sufocado de comoção, apertava contra a própria face com uma ternura indizível, com uma expressão de perplexidade em cada traço de seu rosto.

- Ah, mas mãe, queridíssima mãe! O que foi que afinal te fizemos, não te amamos sempre, não anelamos por ti como o melhor que possuíamos no mundo, tanto quando estávamos junto contigo como quando estávamos longe de ti? Não conhecemos nosso pai senão através de ti, foste tu que nos ensinaste a amá-lo, e se Ellinor e eu gostamos tanto um do outro, não é porque tu, dia após dia, mostraste incansavelmente a um o que havia de digno a amar no outro, e não foi assim com cada pessoa a quem nos ligamos, não temos tudo de ti? Tudo temos de ti, e te veneramos, mãe, se soubesses... Ah, tu não suspeitas quão frequentemente nosso amor por ti anseia por ultrapassar todas as margens e fronteiras rumo a ti, mas foste de novo tu que nos ensinaste a contê-lo, e jamais ousamos nos aproximar tão fervorosamente de ti como tanto teríamos gostado. E agora dizes que queres afastar-te inteiramente de nós, empurrar-nos completamente para o lado! Mas isso é impossível; o que alguém que quisesse o pior no mundo para nós poderia fazer contra nós que fosse tão terrível quanto isso; e tu não queres o pior no mundo para nós, queres o que é bom para nós; como é que isso pode ser possível? Apressa-te a dizer que isso não era verdade, diga "isso não era verdade, Tage, isso não era verdade, Ellinor".

- Tage, Tage, trata de recompor-te e não tornes as coisas tão difíceis, tanto para ti quanto para nós.

Tage se levantou.

- Difíceis! - disse ele -, difíceis, difíceis, ah, quisera que as coisas não fossem nada mais do que difíceis, mas elas são terríveis... são antinaturais; são de enlouquecer, quando se pensa nelas. Tens realmente ideia do que me deste para pensar? Minha mãe sujeitando-se às carícias de um homem estranho, minha mãe cobiçada, abraçada e retribuindo o abraço, ah, esses são pensamentos para um filho, pensamentos piores do que o pior ultraje... mas isso é impossível, isso deveria ser impossível, deveria; pois não deveriam as súplicas de um filho ter a força para tanto? Ellinor, não fiques aí sentada chorando, venhas e me ajudes a pedir à mãe para que tenha compaixão de nós.

A sra. Fønss fez um movimento desaprovador com a mão e disse: 
- Deixa Ellinor em paz, ela já deve estar bastante cansada, e, além do mais, eu disse que nada pode ser mudado.

- Eu desejaria estar morta - disse Ellinor -, mas tudo o que Tage diz é verdade, mãe, e jamais poderá ser correto da tua parte dar-nos um padrasto na idade em que estamos.

- Padrasto! - vociferou Tage -, espero que ele não ouse sequer por um momento... Estás louca, onde ele entrar, de lá sairemos, não há poder na Terra que possa me fazer tolerar a mínima vida em comum com esse homem. Cabe à mãe escolher; ou ele ou nós! Se os recém-casados forem à Dinamarca, nós seremos banidos; se ficarem aqui, nós não ficaremos.

- É essa a tua opinião, Tage? - perguntou a sra. Fønss.

- Não creio que duvides; imagina só a vida familiar: Ida e eu sentados lá fora no terraço numa noite de luar, e há alguém sussurrando por trás do bosquete de loureiros, e Ida pergunta quem está sussurrando e eu respondo: "São minha mãe e seu novo marido". Não, não, eu não deveria ter dito isso; mas já vês o resultado, que dano isso me causou, e isso tampouco fará bem a Ellinor, podes acreditar.

A sra. Fønss deixou os filhos irem e ficou sentada sozinha.

Não, Tage tinha razão, isso não lhes fizera bem; o quanto já tinham se afastado dela nessa breve hora; o modo como a olhavam, não como filhos seus, mas como filhos de seu pai, e como estavam prontos a se livrar dela apenas tinham percebido que nem todo sentimento em seu coração lhes pertencia; mas ela não era única e exclusivamente a mãe de Tage e de Ellinor, ela era uma pessoa por si só, com uma vida por si só e uma esperança por si só, mesmo sem ligação com eles. Mas ela talvez não fosse tão jovem quanto acreditara ser. Percebera-o nessa conversa com os filhos. Não estivera ali sentada, receosa apesar de suas palavras, e quase se sentira como aquela que interferiu no direito da juventude, e toda a segura natureza exigente da juventude e sua ingênua tirania não perpassaram tudo o que eles tinham dito - somos nós quem devemos ser amados, é a nós que a vida pertence e a vida da senhora está aí para nós -?

Ela começou a compreender que poderia haver uma satisfação em ser completamente velha, não que o desejasse, mas isso lhe sorria fracamente como uma paz distante, agora, depois de toda a agitação em que estivera nos últimos tempos, agora, quando a perspectiva de uma discórdia tão grande estava tão próxima. Pois ela não acreditava que os filhos viessem a mudar de ideia, e afinal tinha de falar com eles de novo e de novo a respeito antes de abandonar as esperanças. O melhor era que Thorbrøgger viajasse imediatamente; se ele não estivesse presente, talvez os filhos não ficassem tão irritáveis e ela pudesse lhes mostrar o quanto estava 
ávida por tratá-los com toda a consideração possível; assim a primeira amargura teria tempo de desaparecer e tudo... não, ela não acreditava que tudo ficaria bem.

Foi assim que Thorbrøgger concordou em viajar à Dinamarca para colocar os papéis deles em ordem. Por ora, ele deveria ficar por lá. Entretanto, não parecia que se ganhara algo com isso. Os filhos a evitavam, Tage estava sempre com Ida ou com o pai dela, e Ellinor sempre precisava fazer companhia à enferma sra. Kastager. E quando finalmente estavam juntos, onde estavam não apenas a antiga familiaridade, o antigo aconchego, mas os mil assuntos de conversa, e, se por fim encontrassem um, onde ficara o interesse por ele? Estavam ali sentados e mantinham uma conversação como pessoas que por algum tempo desfrutaram de coisas boas em mútua companhia e que agora precisam se separar, e as que precisam viajar têm todos os seus pensamentos concentrados no destino da viagem, e aquelas que precisam ficar pensam apenas em como retornarão a uma vida caseira e a costumes caseiros quando os visitantes tiverem partido.

Não havia mais nada em comum em suas vidas, todo sentimento de pertença mútua desaparecera. Podiam falar sobre como se arranjariam na próxima semana, no próximo mês, mesmo dali a um mês, mas isso não os interessava como se fossem dias de suas vidas que importassem, apenas como um tempo de espera que cabia superar de um modo ou de outro, pois todos os três se perguntavam em seus pensamentos: "E agora?", pois não podiam sentir qualquer segurança em suas vidas, pois não tinham qualquer alicerce sobre o qual pudessem construí-las antes que estivesse em ordem aquilo que os separara.

E com cada dia que passava, os filhos esqueciam mais e mais o que sua mãe lhes havia sido, tal como filhos que, quando acreditam que lhes fizeram uma injustiça, esquecem mil boas ações por uma única injustiça.

Tage era o mais sensível dos dois, mas também o mais profundamente magoado, pois havia sido aquele que mais amara. Ele chorara longas noites pela mãe que não pudera manter exatamente como queria, e houve momentos em que as lembranças do amor dela por ele quase entorpeceram qualquer outro sentimento em seu peito. Certo dia, também fora até ela e lhe suplicara e mendigara para ser deles, só deles e de mais ninguém, e o que conseguira foi: um não. E esse não o tornara duro, e também frio, uma frieza que de início o assustara, pois junto com ela viera um vazio tão terrível.

Com Ellinor foi diferente; de um modo estranho, sentiu isso mais como uma injustiça contra seu falecido pai, e começou uma adoração fetichista desse pai, de quem só conseguia se 
recordar de modo bastante obscuro, e assim o tornou vivo para si ao se aprofundar em tudo o que ouvira sobre ele, perguntar sobre ele a Kastager e a Tage, beijar toda manhã e toda noite um medalhão que tinha com um retrato dele e ansiar com uma ânsia algo histérica por cartas dele que estavam em casa e por coisas que lhe pertenceram.

Ao mesmo tempo em que o pai ascendia desse modo, a mãe decaía. O fato de ter se apaixonado por um homem a tornava menor aos olhos da filha; ela não era mais a mãe, a infalível, a mais inteligente, a melhor, a mais bela, era uma mulher como as outras, não inteiramente, mas, por não sê-lo inteiramente, alguém que justamente por isso se podia criticar e julgar e em quem se podia achar fraquezas e defeitos. Ellinor estava contente por não ter confidenciado à mãe seu amor infeliz; ela não sabia o quanto se devia à própria mãe o fato de não tê-lo feito.

Um dia passava e outro dia passava e essa vida se tornava cada vez mais insuportável, e os três sentiam que ela era inútil e que, em vez de aproximá-los, separava-os uns dos outros.

A sra. Kastager, que recuperara a saúde e que absolutamente não tomara parte em nada do que acontecera, mas que era, de todos, quem mais estava a par dos fatos, pois tudo lhe fora contado, teve certo dia uma longa conversa com a sra. Fønss, que ficou contente por ter alguém que pudesse ouvir tranquilamente como ela imaginava ordenar seu futuro; e, nessa conversa, a sra. Kastager sugeriu que os filhos fossem com ela a Nice, que Thorbrøgger fosse chamado a Avignon e que ali se casassem. Kastager poderia muito bem ficar e ser testemunha.

A sra. Fønss hesitou por algum tempo, pois não lhe era possível saber a opinião dos filhos; quando lhes contaram a respeito, acolheram a notícia com um nobre silêncio, e quando foram pressionados a uma resposta, apenas disseram que naturalmente teriam de se conformar com o que ela decidiria.

O que a sra. Kastager sugeriu foi feito; a sra. Fønss despediu-se dos filhos e eles partiram, Thorbrøgger veio e eles se casaram.

A Espanha se tornou sua pátria, escolhida por Thorbrøgger devido à criação de ovelhas.

Nenhum deles queria voltar à Dinamarca.

E assim viveram felizes na Espanha.

Ela escreveu algumas vezes aos filhos, mas, em meio à primeira e violenta fúria por ela os ter deixado, eles mandaram as cartas de volta. Arrependeram-se disso mais tarde, mas, ainda assim, não foram capazes de reconhecê-lo diante dela e escrever-lhe, e assim cessou toda 
ligação entre eles. Mas, aqui e ali, por outros caminhos, ficavam sabendo das vidas uns dos outros.

Por cinco anos Thorbrøgger e sua esposa viveram felizes, mas então ela ficou repentinamente doente. Era uma doença que consumia com rapidez e necessariamente terminaria com a morte. As forças se esvaneciam de hora em hora, e um dia, quando a sepultura já não estava mais longe, ela escreveu aos filhos.

"Queridos filhos!" - escreveu ela -, "sei que lereis esta carta, pois não a recebereis antes que eu esteja morta. Não temais, não há recriminações ocultas nestas linhas; possa eu apenas ter conseguido que elas contenham amor o bastante!

"Quando as pessoas amam, Tage e Ellinor, pequena Ellinor, aquela que mais ama sempre tem de se humilhar, e por isso venho mais uma vez até vós, como virei em pensamentos até vós cada hora do dia enquanto puder. Aquele que deve morrer, queridos filhos, é muito pobre; eu sou muito pobre, pois todo este aprazível mundo, que por tantos anos foi minha rica e abençoada casa, deve ser-me tirado, minha cadeira deve ficar vazia, a porta deve fechar-se atrás de mim e nunca mais devo colocar meus pés nele. Por isso vejo todas as coisas com uma súplica em meus olhos para que gostem de mim, por isso venho e vos peço para que me ameis com todo o amor que uma vez me destes, pois lembrai-vos de recordar, essa é toda a parte que a partir de agora me cabe no mundo dos homens. Apenas recordar, nada mais.

"Jamais duvidei de vosso amor; bem soube que foi vosso grande amor que causou vossa grande ira; tivésseis me amado menos, também me deixaríeis ir mais tranquilamente. E, por isso, quero dizer-vos que se um dia acontecer que um homem vergado pelo pesar venha até vossa porta para falar convosco sobre mim, falar sobre mim para seu próprio consolo, lembraivos de que não há ninguém que tenha me amado como ele e que toda a felicidade que pode irradiar de um coração humano adveio dele para mim. E logo, na última e grande hora, ele segurará minhas mãos quando a escuridão chegar, e suas palavras serão as últimas que ouvirei...

“Adeus, digo aqui, mas não é o último adeus para vós, que direi tão tarde quanto me atrever, e nele deverá estar todo o meu amor e a saudade de tantos, tantos anos, e lembranças de quando éreis pequenos, e milhares de desejos e milhares de agradecimentos. Adeus Tage, adeus Ellinor, adeus até o último adeus.

\section{Vossa mãe."}




\section{REFERÊNCIAS BIBLIOGRÁFICAS}

JACOBSEN, Jens Peter. "Fru Fønss". In: Mogens og andre Noveller. 5.ed. København og Kristiania: Gyldendal, 1906, p. 373-421. (Samlede Skrifter, 2)

JENSEN, Morten Høi. A Difficult Death: The Life and Work of Jens Peter Jacobsen. New Haven and London: Yale University Press, 2017. 